\title{
A NEW FUZZY LOGIC BASED CAREER GUIDANCE SYSTEM: WEB-CGS
}

\author{
Musa Peker, Hüseyin Gürüler, Baha Şen, Ayhan İstanbullu
}

Original scientific papers

Choosing a career affects individuals' social life deeply in terms of many dimensions. However, choosing the right career is becoming increasingly difficult given the existence of an increasing number of professions and training opportunities. Consequently, the importance of career orientation increases. In this study, a system that can automatically offer vocational guidance has been developed. This new system is referred to as WEB-CGS (webbased carrier guidance system) and works as a fuzzy logic based web service. The aim is that it will make it easier for an individual to choose the right profession. In this system, students' prior educational successes and teachers' views were integrated in a manner which made it possible to identify the students' professional interests and capacities. The system forecasts vocational school students' interest with regard to Information Technology, ElectricsElectronics, Accounting, and Automotive. Promising results were obtained with regard to 300 unbiased $9^{\text {th }}$ grade students in terms of orienting them towards an appropriate profession.

Keywords: artificial intelligence; career guidance; higher education; student profiling

Novi sustav profesionalnog usmjeravanja zasnovan na neizrazitoj logici: WEB-CGS

Izvorni znanstveni članak

Izbor zanimanja na mnogo načina uvelike utječe na društveni život pojedinaca. Ipak, izbor odgovarajuće karijere postaje sve teži kad se uzme u obzir postojanje sve većeg broja zanimanja i mogućnosti usmjeravanja. Shodno tome, sve je veća važnost profesionalnog usmjeravanja. U ovom se radu razvija sustav pomoću kojega se automatski može ponuditi profesionalno usmjeravanje. To je WEB-CGS (web-based carrier guidance system) koji funkcionira kao web usluga koja se zasniva na neizrazitoj (fuzzy) logici. Cilj je olakšati pojedincu izbor odgovarajućeg zanimanja. U tom sustavu integrirani su prethodni uspjesi u obrazovanju učenika i mišljenja nastavnika te je omogućeno prepoznavanje profesionalnih interesa i mogućnosti učenika. Sustav predviđa interes učenika za usmjeravanje u području informacijske tehnologije, elektrike-elektronike, računovodstva i industrije automobila. Postignuti su obećavajući rezultati usmjeravanja za 300 neopredijeljenih studenata 9. razreda u strukovnoj srednjoj školi.

Ključne riječi: profiliranje studenata; više obrazovanje; vođenje karijere; umjetna inteligencija

\section{Introduction}

A profession can be defined as the total of activities which are undertaken to earn a living, the rules of which are determined by the public and are acquired through specific education, based on knowledge and skills. Choosing a profession is one of the most important decisions in life. Career guidance is a supporting service that helps people to select a suitable profession [1]. The main aim of career guidance services is to orient individuals, each of whom has completely different characteristics and differing fields of intelligence, towards the most appropriate careers in terms of their specific characteristics and fields of interest [1].

A large number of factors affect career guidance, and some difficulties in its processing have led to increased attention to computer-assisted career guidance (CACG) systems [2]. The effectiveness and use of such systems have been reviewed in $[3,4]$. Since the 1960s, CACG systems have resulted in very effective and efficient results in this field [5]. Some outstanding studies on CACG systems have been introduced in [6-13]. Experimental researches relating to the effect of such systems on the self-efficacy of career decision have been indicated in [6, 12-14]. As most of the researchers [9, 1520] have expressed, the effects of CACG systems are only revealed; they are used with other career interventions and psychological consultation techniques. Gati [8], in particular, expressed that CACG systems need to be applied within the education system. He also indicated the need for using valid tools in parallel to developing technology.
Some studies in the literature on CACG systems relating to SIGI PLUS [21], DISCOVER [22], CHOICES [23] can be identified. Besides providing information about different occupations, these programs allow us to obtain specific metrics that are required during orientation, such as personal characteristics, abilities, interests, educational values, occupational choices and preferences. DISCOVER is a computer program that assists people with self-assessment, and provides information related to making career decisions [22]. SIGI PLUS is similar. However, it does not provide information on post-secondary education [21, 24]. CHOICES should be used under the guidance of a vocational counsellor [23]. It helps the job seeker to learn more about abilities and interests and how they may relate different careers [25]. CACG applications in the literature have been conducted in the form of desktop programs. No web-based application has been found in the literature.

One thing is certain; vocational guidance requires taking into account the variables specific to each country. Therefore, the development of vocational guidance software that fits with our education system has been deemed necessary. Therefore, this study aims to develop an automated system for vocational guidance activities which can be applied to students in the final year of secondary school. However, the applications in the literature mentioned above are only informative. So, there is no automatic guidance process in these applications. Here, the aim is to increase the efficiency of vocational guidance by the introduction of an artificial intelligence approach. The percentage of students tending towards each profession has been determined by using the academic success of the student, his/her interest and 
ability determined as a result of surveys, and teacher's opinions about the student as input variables.

The proposed web-based system, namely WEB-CGS, was developed as a hybrid model that made use of the ASP.NET for the web basis of the study while a MATLAB fuzzy logic tool was utilized during the rule setup. The user does not require any knowledge of the installation and use of these pieces of software. In this respect, this system can offer a service for all target schools.

This article comprises four sections. In section 2 , a brief description of the methods and dataset used in this study is provided. In this section, the details of the proposed diagnosis system are given. In section 3, the experimental results are summarized. Finally, Section 4 offers the conclusions derived from the study.

\section{Materials and Methods 2.1 Dataset}

Student data for the study was collected with the cooperation of educational experts working with $9^{\text {th }}$ grade students at the Samandira Technical and Vocational High School, Istanbul. The students in the study were oriented to various vocational departments using the methods mentioned in the first sections of the study. Tab. 1 presents a sample data set for 20 students in various departments with the aforementioned entry data.

Table 1 Features of 20 students

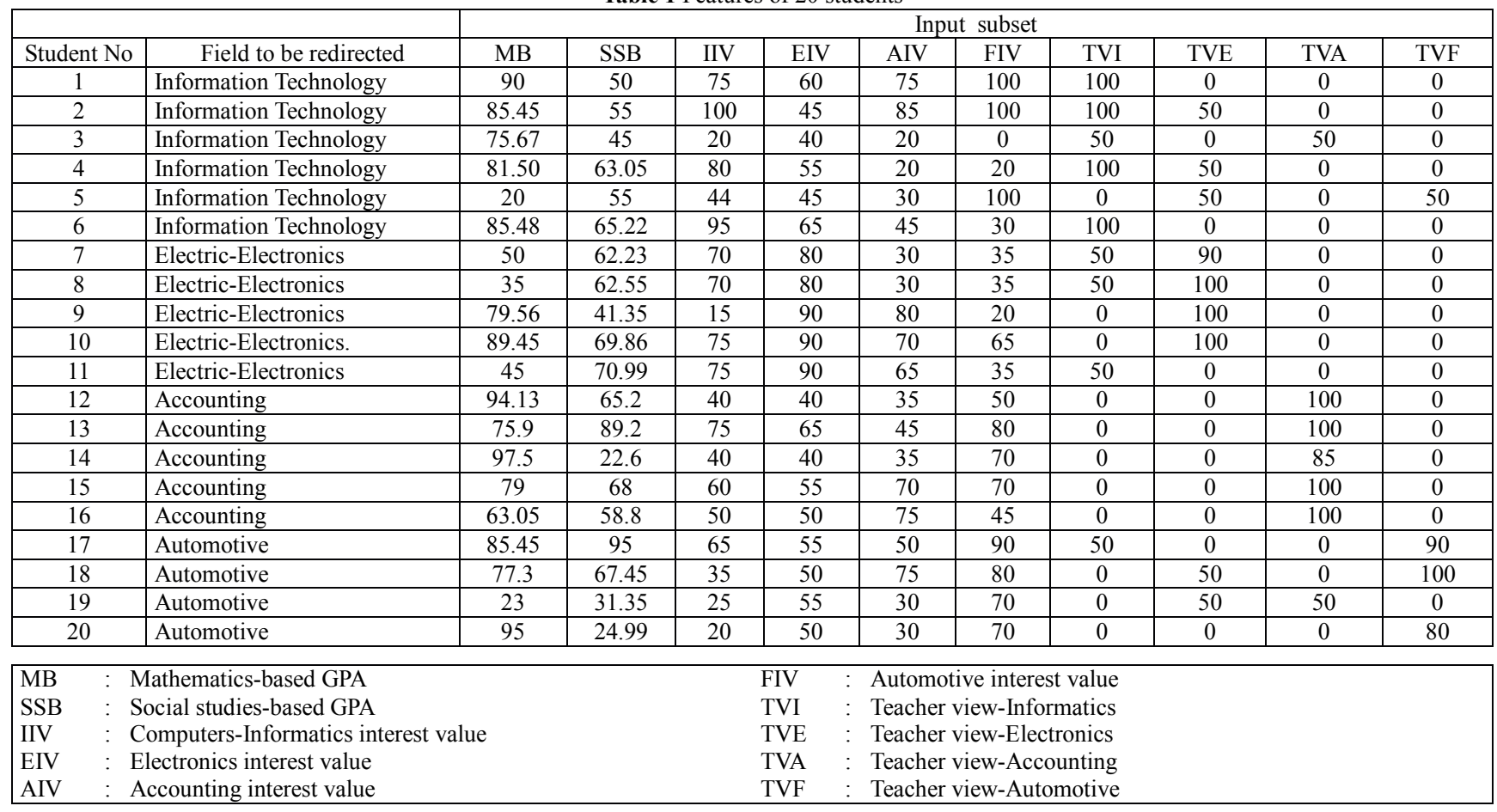

The averages of the vocational classes for the students in the $10^{\text {th }}$ and $11^{\text {th }}$ grades were calculated in order to test the accuracy of the results obtained by using Mamdani's fuzzy logic method. In order to test the results, student grades from the vocational classes were compared with the results obtained through the fuzzy logic model.

\subsection{Fuzzy logic model}

The concepts of the fuzzy logic system were first introduced by Zadeh [26]. Fuzzy logic has been applied in a wide range of areas from medicine to engineering, from space and aviation to control systems and to earth sciences [27].

Fuzzy logic is an information-based system which transforms, through rules and membership functions, the linguistic expressions to rule-based data [28]. Establishing a fuzzy logic model starts with the identification of input and output linguistic variables and the shaping of the fuzzy rules [26, 29-31]. The fuzzy numbers, used in the expression of linguistic variables, can take different shapes such as triangular, trapezoid, bell shaped and curved. Generally, triangular and trapezoid shaped membership functions are preferred since they provide ease in the presentation of expert knowledge and simplify computations. The basic elements of a fuzzy logic system can be seen in Fig. 1.

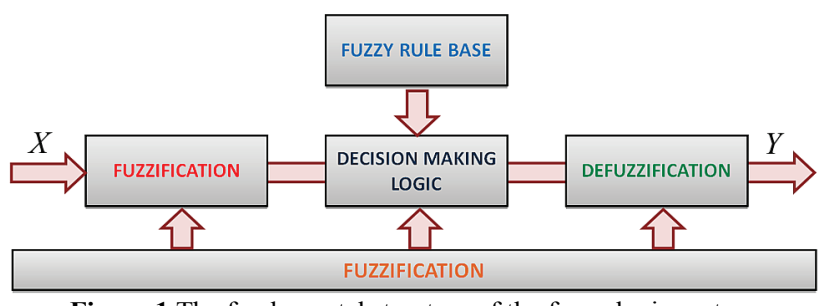

Figure 1 The fundamental structure of the fuzzy logic system

The fuzzification process involves transforming entry values from the system's symbolic values which are linguistic qualifiers. The membership function is used to associate a grade to each linguistic term of fuzzy sets such as small, the smallest, etc. After the input and output values of the model or the controller are determined, and expression sets (such as little, very hot, cold) are selected for the variables, the rules are used from the rules base to establish the relationships between inputs and outputs. 
The output unit, which uses the fuzzified inputs and the rules from the rules base, processes the incoming data and provides an output (fuzzy). Since this output is used in the real world (in the real system), the fuzzy values need to be turned into real values. This process is called defuzzificiation [32].

\subsubsection{The principles of Mamdani fuzzy model}

The Mamdani fuzzy model is established very easily and is very suitable for human behaviour [33]. For these reasons, it is commonly used, and it forms the basis of the other fuzzy logic models. It was first used to control a steam engine with the help of linguistic control rules derived from human experiences [33]. In this model, both input and output variables were expressed with the membership functions in the closed form [33].

The Mamdani fuzzy model is formed in 5 steps - the fuzzification of the input, the identification of rule weights by using fuzzy logic operations, the application of fuzzy set logical processors (and, or), the integration of fuzzy sets which represent the output of each rule, and the clarification of the total fuzzy set results which are transformed into a numerical value.

\subsection{Design of an orientation system with regard to a fuzzy logic model}

The first step in applying fuzzy logic to a system is to identify the system's inputs and outputs. In this study, the input set consisted of the GPAs in $9^{\text {th }}$ grade Mathematicsbased and Social Studies-based classes; career interest values obtained through questionnaires; and teacher-view values input set, acquired through interviewing classroom guidance teachers. The output set consists of the careers point values of four fields. These are Information Technology, Electrics-Electronics, Accounting, and Automotive. Naturally, the input range of each fuzzy set is different according to its weight. All of the fuzzy logic operations were carried out using a newly developed webbased system, namely WEB-CGS. Fig. 2 shows an example user interface of the WEB-CGS.

Fig. 3 illustrates the system's block schema which are designed to identity the professional tendencies.

- GPAs (MB, SSB): these were the average of annual mean values of $9^{\text {th }}$ grade students in Mathematicsbased and Social Studies-based classes. The GPA in Mathematics-based classes consisted of the means of Physics, Chemistry, Biology and Mathematics classes, while the GPA in the Social Studies-based classes consisted of the means of History, Geography and Language classes at the end of the year.

- Teacher views (TV): This was the value which showed the students' disposition towards specific careers. This was obtained through one-on-one interviews with students, and through acquiring the views of parents and other teachers who knew the student. When determining the value, the teachers considered all 4 fields to determine the student's disposition.

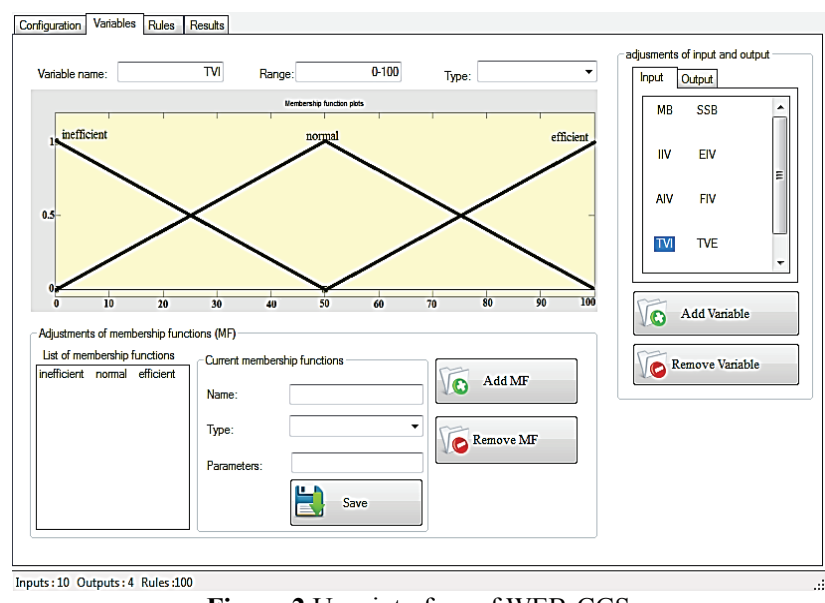

Figure 2 User interface of WEB-CGS

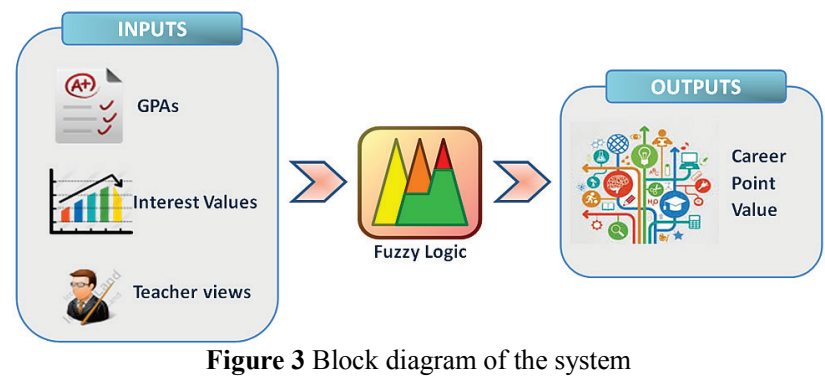

- The professional/vocational interest values: A vocational/professional disposition questionnaire with 150 questions was prepared in order to determine the students' interests and capabilities. The questionnaire was administered to 300 students. In the questionnaire, there were questions belonging to the above-mentioned four parts in terms of professional interest. There was an equal number of questions for each part. These questions were prepared with the assistance of the Ministry of National Education's guidance experts. Some of the questions in the questionnaires were selected from the Kuder Professional Tendency Inventory [34]. The answers to the questions required answers in the form of 'Yes, No and Sometimes'.

The student received 100 points for answering 'Yes', 50 points for answering 'Sometimes' and zero points for answering 'No' according to his/her field, to determine the percentage of disposition. According to the answers given, the means for each field were calculated, and the interest for specific fields was determined (See Fig. 4).

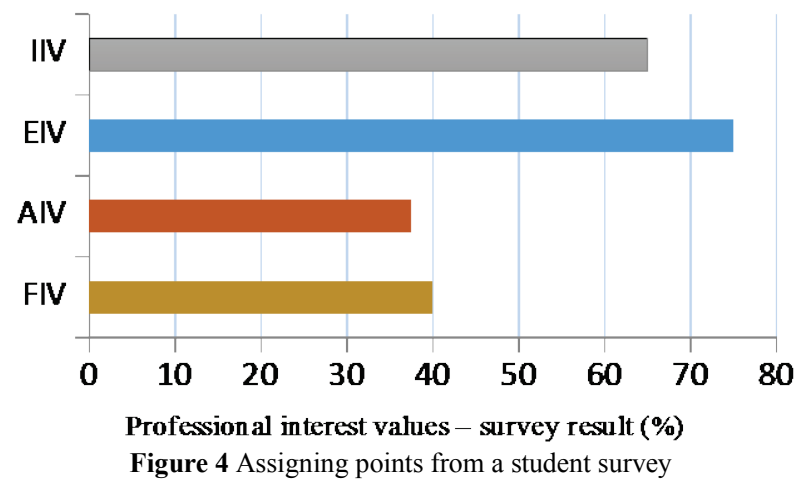


Hundred rules were established amongst the parameters which had an effect on the system after the membership functions of the necessary parameters and low and high limits were determined.

Ten input variables were entered into the system as linguistic expressions; the rules were operated using the Mamdani extraction mechanism to find the output membership function values. The Centre of Gravity (centroid) method was used for the defuzzificiation process in terms of the output variables in the fuzzy system [35]. A mathematical statement of this method is presented in Eq. (1). The defuzzificiation process was calculated by automatically loading the data and rules into the system.

$$
z^{*}=\frac{\sum \mu(z) \cdot z}{\sum \mu(z)}
$$

Here, $\mu(z)$ was obtained as a result of the extraction process of the weight of membership, $z$ the output value of each rule, while $z^{*}$ represents the defuzzified value output. The defuzzificiation process took place automatically in the developed software environment.

\section{Experimental results and discussions}

In this study correlation coefficient, mean absolute error, confusion matrix, and classification accuracy were used for the performance evaluation.

- Coefficient of determination: it is simply the square of the correlation coefficient. In the event that the coefficient of determination is close to 1 , the linear dependence between $X$ and $Y$ variables is strengthened. In this study, the coefficient of determination obtained through a comparison between the current GPAs from vocational classes and the GPAs obtained from the output of the fuzzy logic system was calculated as 0.89 .

- Mean absolute error: this is the value obtained by the addition of percentages for each result obtained from dividing the observed and forecast data value differences in a series to observed values. The error between the desired value and the result of the fuzzy logic model is absolute and, in a situation in which this value is close to zero, we can say that the result is statistically close to the desired value. In this study, the average absolute error is calculated at around 0.02 . The fuzzy logic system forecasts were correct as indicated by the fact that the mean absolute error value was low, and that the correlation coefficient was close to 1 .

- Confusion matrix: The confusion matrix shows the classification of the cases in the test dataset. In a confusion matrix, the columns denote the actual cases, and the rows denote the predicted. Tab. 2 shows the confusion matrix for a two class classifier. The entries of our confusion matrix can be interpreted as follows. In Tab. 2, $x$ is the number of correct predictions that an instance is negative; $y$ is the number of incorrect predictions that an instance is positive, $z$ is the number of incorrect predictions that an instance is negative and $w$ is the number of correct predictions that an instance is positive.

Table 2 Confusion matrix
\begin{tabular}{|l|c|c|}
\hline \multicolumn{2}{|c|}{ Predicted } \\
\hline Actual & Negative & Positive \\
\hline Negative & $x$ & $y$ \\
\hline Positive & $z$ & $w$ \\
\hline
\end{tabular}

Table 3 Comparison results of 15 students

\begin{tabular}{|c|c|c|c|c|}
\hline $\begin{array}{l}\stackrel{0}{Z} \\
\frac{0}{0} \\
\frac{0}{0} \\
\frac{0}{0}\end{array}$ & Field to be Redirected & 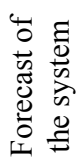 & 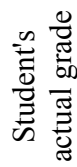 & 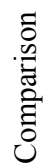 \\
\hline 1 & Information Technology & 4 & 4 & \\
\hline 2 & Information Technology & 5 & 5 & \\
\hline 3 & Information Technology & 3 & 1 & \\
\hline 4 & Information Technology & 4 & 4 & \\
\hline 5 & Electric-Electronics & 4 & 2 & \\
\hline 6 & Electric-Electronics & 0 & 0 & \\
\hline 7 & Electric-Electronics & 5 & 4 & \\
\hline 8 & Electric-Electronics & 5 & 5 & \\
\hline 9 & Electric-Electronics & 3 & 3 & \\
\hline 10 & Accounting & 4 & 4 & \\
\hline 11 & Accounting & 5 & 5 & \\
\hline 12 & Accounting & 3 & 3 & \\
\hline 13 & Automotive & 5 & 5 & \\
\hline 14 & Automotive & 4 & 4 & \\
\hline 15 & Automotive & 0 & 1 & \\
\hline
\end{tabular}

- Classification accuracy $(C A)$ : The percentages with regard to classification accuracy were found as follows:

$$
C A=\frac{\text { Correct Classified Patterns }}{\text { Total Patterns }} \times 100 \%
$$

In Tab. 3, the comparison results of 15 students have been listed as an example. The current grade point averages (GPAs) from vocational classes and the GPAs obtained from output of fuzzy logic system are shown in Tab. 3. The prediction results of the proposed method are presented in Tab. 4.

Table 4 The comparison of the current GPAs from vocational classes and the GPAs obtained from output of fuzzy logic system

\begin{tabular}{|c|c|c|c|c|c|c|c|}
\hline Scale & 0 & 1 & 2 & 3 & 4 & 5 & Accuracy \\
\hline 0 & 32 & 2 & 2 & 2 & 0 & 0 & 84.21 \\
\hline 1 & 0 & 46 & 4 & 0 & 2 & 0 & 88.46 \\
\hline 2 & 0 & 4 & 43 & 1 & 0 & 0 & 89.58 \\
\hline 3 & 0 & 0 & 3 & 36 & 1 & 2 & 85.71 \\
\hline 4 & 0 & 1 & 0 & 2 & 40 & 0 & 93.02 \\
\hline 5 & 1 & 0 & 0 & 1 & 2 & 73 & 94.80 \\
\hline \multicolumn{10}{|c|}{} \\
\hline
\end{tabular}

The results presented in Tab. 4 are the 10 -fold cross validation results. Since the output variable had six values, the confusion matrix shows a $6 \times 6$ square matrix. In the confusion matrices, the rows represent the actual 
and the columns represent the predictions. The right-most columns show the prediction accuracies for each of the six output variable values. The overall accuracy of each model is presented at the bottom of the right-most columns. According to the results, the system calculated the GPAs of 270 out of 300 students correctly. The success of the system was calculated to be $90 \%$.

This system numerically predicts student achievement for all professions before receiving vocational training. In order to test the success of the system, the average of the actual training courses has been compared with these estimated values.

\section{Discussion and Conclusions}

This study proposes a fuzzy-based alternative method to traditional career guidance practices, and introduces the web-based career guidance system, WEB-CGS. The system involving the use of the Mamdani fuzzy logic method which was used in the study successfully, has forecast vocational school students' interests with regard to the fields of Information Technology, ElectricsElectronics, Accounting, and Automotive. Additionally, the system makes it easier to use the guidance system with respect to traditional methods.

The study involved the use of input sets consisting of the GPAs of mathematics-based and social studies-based classes, and career interest values. This was done by means of questionnaires and a teacher-view values input set acquired through interviewing classroom guidance teachers. In this study, the output set was determined with regard to four profession fields. Thus a more comprehensive study applied to all profession fields could usefully be undertaken.

Vocational guidance is a work that requires taking into account local and specific factors. Therefore, a more advanced and more stable system could be developed by increasing input and output sets. Moreover, these inputoutput sets could be varied according to the different types of school.

More reliable fuzzy rules could be created by testing this study on a larger number of students. However, it should be taken into account that the developed system is just a prototype at the moment. Currently, it is designed for vocational schools and, as a result, it can only be used for this type of school. However, it is important to note that the developed system provides vocational guidance based on objective data and being able to measure the error.

Finally, we believe that the developed vocational guidance system described in this paper will give good support to advisers and consultants in secondary schools.

\section{References}

[1] Alexander, P. M.; Holmner, M.; Lotriet, H. H.; Matthee, M. C.; Pieterse, H. V.; Naidoo, S.; Twinomurinzi, H.; Jordaan, D. Factors Affecting Career Choice: Comparison between Students from Computer and Other Disciplines. // Journal of Science Education and Technology. 20, (2011), pp. 300315. https://doi.org/10.1007/s10956-010-9254-3

[2] Shahnasarian, M.; Peterson, G. W. The Effect of a Prior Cognitive Structuring Intervention with Computer-Assisted
Career Guidance. // Computers in Human Behavior, 4 2(1988), pp. 125-131 https://doi.org/10.1016/0747-5632(88)90021-0

[3] Hughes, K. L.; Karp, M. M. School-Based Career Development: A Synthesis of the Literature. New York: Columbia University, Teachers College, Institute on Education and the Economy, 2004.

[4] Sampson Jr, J. P.; Rudd, E.; Reardon, R. C. ComputerAssisted Career Guidance: Research and Evaluation Bibliography. Tallahassee: Florida State University, Center for the Study of Technology in Counseling and Career Development, 1998.

[5] Bozgeyikli, H.; Dogan, H. The Effect of Computer Assisted Career Group Guidance on the Self-Efficacy Levels of Career Decision Making in Students. // European Journal of Educational Studies. 2, 2(2010). pp. 77-86.

[6] Fukuyama, M. A.; Probert, B. S.; Neimeyer, G. J.; Nevill, D. D.; Metzler, A. E. Effects of DISCOVER on the Career Self-efficacy and Decision Making of Undergraduates. // Career Development Quarterly. 37, (1988), pp. 56-62. https://doi.org/10.1002/j.2161-0045.1988.tb00801.x

[7] Garis, J.; Bowlsbey, J. H. DISCOVER and the Counselor: Their Effects Upon College Student Career Planning Progress. (ACT Research Report No. 85). Iowa City, IA: ACT Publications, 1984.

[8] Gati, I. Computer-Assisted Career Counseling: Dilemmas, Problems, and Possible Solutions. // Journal of Counseling and Development. 73, (1994), pp. 51-56. https://doi.org/10.1002/j.1556-6676.1994.tb01709.x

[9] Glaize, D. L.; Myrick, R. D. Interpersonal Groups or Computers? A Study of Career Maturity and Career Decidedness. // Vocational Guidance Quarterly. 32, (1984), pp. 168-176. https://doi.org/10.1002/j.2164-585X.1984.tb01576.X

[10] Luzzo, D. A.; Pierce, G. Effects of DISCOVER on the Career Maturity of Middle School Students. // Career Development Quarterly. 45, (1996), pp. 170-172. https://doi.org/10.1002/j.2161-0045.1996.tb00267.x

[11] Marin, P.; Splete, H. A Comparison of the Effect of Two Computer-based Counseling Inventions on the Career Decidedness of Adults. // The Career Development Quarterly. 39, 4(1991), pp. 360-371. https://doi.org/10.1002/j.2161-0045.1991.tb00304.x

[12] Oliver, L. W.; Spokane, A. R. Career-Intervention Outcome: What Contributes to Client Gain? // Journal of Counseling Psychology. 35, (1988), pp. 447-462. https://doi.org/10.1037/0022-0167.35.4.447

[13] Whiston, S. C.; Sexton, T. L.; Lasoff, D. L. CareerIntervention Outcomes: A Replication and Extension of Oliver and Spokane. // Journal of Counseling Psychology, 45, (1998), pp. 150-165. https://doi.org/10.1037/0022-0167.45.2.150

[14] Pinder, F. A.; Fitzgerald, P. W. The Effectiveness of a Computerized Guidance System in Promoting Career Decision-Making. // Journal of Vocational Behavior, 24, (1984), pp. 123-131. https://doi.org/10.1016/0001-8791(84)90071-X

[15] Brown, D.; Lent, W. Career Development and, Career Counseling, and Career Development. 10th ed. John Wiley \& Sons., Canada, 2005.

[16] Garis, J. W.; Niles, S. G. The Separate and Combined Effects of SIGI and DISCOVER and a Career Planning Course for Undecided University Students. // Career Development Quarterly. 38, (1990), pp. 261-274. https://doi.org/10.1002/j.2161-0045.1990.tb00387.x

[17] Johnston, J. A.; Buescher, K. L.; Heppner, M. J. Computerized Career Information and Guidance Systems: Caveat Emptor. // Journal of Counseling and Development. 67, (1988), pp. 39-41. https://doi.org/10.1002/j.1556-6676.1988.tb02008.x 
[18] Niles, S, G.; Erford, B. T.; Hunt, B.; Watts Jr, R. H. Decision-Making Styles and Career Development in College Students. // Journal of College Student Development. 38, 5(1997), pp. 479-488.

[19] Taber, B. J.; Luzzo, D. A. A Comprehensive Review of Research Evaluating the Effectiveness of DISCOVER in Promoting Career Development (ACT Research Report Series No. 99.3). Iowa City, IA: American College Testing, 1999.

[20] Watts, A. G. The Politics and Economics of ComputerAided Careers Guidance Systems. // British Journal of Guidance and Counseling. 21, (1993), pp. 175-187. https://doi.org/10.1080/03069889308253654

[21] Educational Testing Service. System of Interactive Guidance and Information. NJ: Publisher, Princeton, 1984

[22] American College Testing Program. DISCOVER (computer program), Iowa City, Iowa, 1988.

[23] STM Systems Corp. Careerware. CHOICES for Adults in Career Transitions (Computer Program). Ottawa, Ontario, 1989.

[24] Peterson, G. W.; Ryan-Jones, R. E.; Sampson Jr., J. P.; Reardon, R. C.; Shahnasarian, M. A Comparison of the Effectiveness of Three Computer-Assisted Career Guidance Systems: DISCOVER, SIGI, and SIGI PLUS. // Computers in Human Behavior. 10, 2(1994), pp. 189-198. https://doi.org/10.1016/0747-5632(94)90002-7

[25] Van Wie, K. O. Academic Advising and Career Development for Undecided Transfer Students. Transfer Students in Higher Education. Eds. Mark Poisel and Sonya Joseph. Columbia, SC: National Resource Center for the First year Experience \& Students in Transition, 2011.

[26] Zadeh, L. A. Fuzzy sets. // Information and Control, 8 , 3(1965), pp. 338-353. https://doi.org/10.1016/S0019-9958(65)90241-X

[27] Sen, Z. Principles of Modelling with Fuzzy Logic in Engineering, Water Foundation Publications, Istanbul, 2004.

[28] Jiang, W.; Lu, J. Fuzzy Logic System for Frequency Stability Analysis of wind farm integrated power systems. // Tehnički Vjesnik - Tehnical Gazette, 22, 5(2015), pp. 11991205 .

[29] Ghose, J.; Sharma, V.; Kumar, N.; Krishnamurthy, A.; Kumar, S.; Botak, Z. Taguchi-Fuzzy Based Mapping of EDM-Machinability of Aluminium Foam. // Tehnički Vjesnik - Tehnical Gazette, 18, 4(2011), pp. 595-600.

[30] Shojafar, M.; Javanmardi, S.; Abolfazli, S.; Cordeschi, N. FUGE: A joint meta-heuristic approach to cloud job scheduling algorithm using fuzzy theory and a genetic method. // Cluster Computing, 18, 2(2015), pp. 829-844. https://doi.org/10.1007/s10586-014-0420-x

[31] Javanmardi, S.; Shojafar, M.; Shariatmadari, S.; Ahrabi, S. S. Fr TRUST: a fuzzy reputation-based model for trust management in semantic p2p grids. // International Journal of Grid and Utility Computing, 6, 1(2014), pp. 57-66. https://doi.org/10.1504/IJGUC.2015.066397

[32] Shehab, E. M.; Abdalla, H. S. Manufacturing Cost Modeling for Product Development. // Robotics and Computer Integrated Manufacturing, 17, 4 (2001), 341-353. https://doi.org/10.1016/S0736-5845(01)00009-6

[33] Mamdani, E. H.; Assilian, S. An Experiment in Linguistic Synthesis with a Fuzzy Logic Controller. // International Journal of Man-Machine Studies. 7, 1(1975), pp. 1-13. https://doi.org/10.1016/S0020-7373(75)80002-2

[34] Kuder, G. F. Kuder Preference Record Vocational, Form C. Chicago: Science Research Associates, 1956.

[35] Murat, Y. S.; Uludag, N. Modeling Route Choice Behavior in Transportation Networks by using Fuzzy Logic and Logistic Regression Techniques. // IMO Technical Journal, (2008), pp. 4363-4379.

\section{Authors' addresses}

Musa Peker, Ph.D.

Department of Information Systems Engineering,

Faculty of Technology, Mugla Sitki Kocman University, 48000 Mugla, Turkey

E-mail: musa@mu.edu.tr

Hüseyin Gürüler, Ph.D.

Department of Information Systems Engineering, Faculty of Technology, Mugla Sitki Kocman University, 48000 Mugla, Turkey

E-mail: hguruler@mu.edu.tr

Baha Şen, Ph.D.

Department of Computer Engineering,

Yıldırım Beyazıt University,

Ankara, Turkey

E-mail: bsen@ybu.edu.tr

Ayhan İstanbullu, Ph.D.

Department of Computer Engineering, Faculty of Engineering, Balikesir University, 10145 Cagis, Balikesir, Turkey

E-mail: iayhan@balikesir.edu.tr 